\title{
EPIDEMIOLOGICAL STUDIES ON TOXOPLASMOSIS IN SMALL RUMINANTS AND EQUINE IN DAKAHLIA GOVERNORATE, EGYPT.
}

\author{
YOUNIS, E.E. ; ABOU-ZEID, N.Z. ${ }^{* *}$; ZAKARIA, M. ${ }^{*}$ and MAHMOUD, M.R. \\ Department of Internal medicine, infectious and fish diseases (Infectious diseases) Faculty of Veterinary Medicine, \\ Mansoura University, Mansoura. Egypt. \\ ** Department of Animal medicine (Infectious diseases), Faculty of Veterinary Medicine, Zagazig University, Zagazig, \\ Egypt. \\ Email: yasserelnaker@yahoo.com \\ Assiut University Email: www.aun.edu.eg
}

Received at: $23 / 2 / 2015$

Accepted: 15/3/2015
Prevalence of toxoplasmosis was investigated in small ruminants (292 sheep \& 81 goats) and equine (54 horses and 79 donkeys) from Dakahlia governorate, Egypt in the period from October 2013 - October 2014. The annually incidences were estimated by using latex agglutination test (LAT); indirect hemagglutination test (IHAT) and enzyme linked immunosorbent assay (ELISA) in sheep were $(41.7 \%),(66.1 \%)$ and $(62.0 \%)$ respectively, in goat were $(49.4 \%),(64.2 \%)$ and $(50.6 \%)$ respectively, in horse $(50.0 \%),(72.2 \%)$ and $(72.2 \%)$ respectively and $(44.3 \%),(67.1 \%)$ and $(68.4 \%)$ in donkeys respectively. The results of bioassay in cats revealed that 8 out of 25 slaughtered sheep (32.0\%) and 9 out of 25 slaughtered donkeys (36.0\%) were positive. Histopathological examination on bioassay positive case detected Toxoplasma gondii (T. gondii) tissue cysts in 3 (37.5\%) and 4 (44.4\%) in diaphragm muscles of sheep and donkeys respectively. The sensitivity of both ELISA and IHAT in sheep and donkeys was $100 \%$. Regarding to host risk factors associated with toxoplasmosis, the results revealed that the seroincidence was significantly higher in equine [horses $(72.2 \%)$ and donkeys $(68.4 \%)$ ] than in small ruminants [sheep (62.0\%) and goats (50.6\%)] and in relation to the gender the females were higher than in males. There are high associations between the history of abortion and intensive rearing system with incidence of toxoplasmosis in sheep. It could be concluded that the equines and small ruminants play an important role in epidemiology of toxoplasmosis. ELISA test is the more suitable test in diagnosis of toxoplasmosis in small ruminant and equine. There are strong association between serodiagnosis of toxoplasmosis with intensive breeding, old ages and female in small ruminant and equine.

Key words: Toxoplasma gondii, sheep, goat, horse, donkey.

\section{INTRODUCTION}

Toxoplasma gondii (T. gondii) was an intracellular cyst-forming apicomplexans protozoan organisms occurring in domestic animals and man throughout the world. It has an indirect life cycle, with feline as the definitive hosts (El-On and Peiser, 2003).

The main source of infection of herbivores is infected omnivores feces, by ingestion of $T$. gondii sporulated oocysts in contaminated food and water. Therefore toxoplasmosis in these animals were significantly associated with the presence of omnivores in the farms. $T$. gondii cysts may persist in the tissues of the host for years (Dubey et al., 1989 and Dubey, 2010).
Most acquired toxoplasmosis in ovine, caprine and equine are subclinical, however fever, ataxia, retinal degeneration and encephalomyelitis may develop. Severity of toxoplasmosis in sheep and goats are associated with the stage of pregnancy. Infection during the early stage of gestation can result in fetal death, resorption and abortion, while infection in the later stage of gestation may have no clinical effect and lambs are usually born normal but infected and immune (Dubey and Beattie, 1988 and Buxton et al., 2007).

Due to the microscopic size and intracellular localization of the proliferative forms of this protozoan parasite and the relative difficulty in its laboratory cultivation, the development of immunodiagnostic tools such as serology and 
immunohistochemistry are essential in the demonstration of infection (Uggla and Buxton, 1990). The aim of the present study was to determine the Incidence and possible risk factors associated with toxoplasmosis in small ruminants (sheep \& goats) and equine (horses and donkeys) from Dakahlia governorates, Egypt.

\section{MATERIALS and METHODS}

\section{Animals}

a) Slaughtered animals: 25 slaughtered sheep at Mansoura abattoir and 25 donkeys slaughtered at Mansoura Zoo were used in serological diagnosis of toxoplasmosis; histopathology and tissues bioassay in cats.

b) Surveyed animals: 267 sheep, 81 goats, 54 horses and 54 donkeys of different sex from different localities in Dakahlia province aged between 3 months to 8 years were used for determination of seroprevalence of toxoplasmosis in sheep and goats and identification of risk factors associated with toxoplasmosis in the period from October 2013 October 2014.

c) Cats: 100 cats $2-3$ months age were used for bioassay of tissue samples taken from slaughtered sheep at abattoir and slaughtered donkeys at zoo (2 cats were used for each tissue sample). They were previously proved free from; Nematodae; Cestodes; Isospora, Eimeria and T. gondii oocysts through fecal examination. Cats were fasted overnight, each 2 cats fed one tissue sample (diaphragm muscles) cut into small pieces using disposable scalpel and then faecal samples of cats were collected daily for 14 days post infection and examined microscopically for oocysts as described by Dubey, (2001) by fecal floatation technique.

\section{Samples:}

a) Blood Samples: $10 \mathrm{ml}$ of blood were collected from examined sheep, goats, donkeys and horses. After clotting at room temperature, blood was centrifuged at $3000 \mathrm{rpm}$ for 10 minutes and the collected sera were stored at $-20^{\circ} \mathrm{C}$ until assayed for antibodies against toxoplasmosis.

b) Tissue Samples: About 50 grams of freshly tissue specimens from diaphragm of slaughtered sheep and donkeys were used for bioassay in cats (2 cats were used for each tissue sample) according to Dubey, (2001) and $50 \mathrm{gm}$ preserved in formalin $10 \%$ used for histopathological examination according to Bancroft and Stevens, (1996).

c) Faecal Samples of cats were collected daily for 14 days post infection and examined microscopically for oocysts as described by Dubey, (2001).

3. Serological examination of serum samples from sheep, goats, horses and donkeys for toxoplasmosis

(1) Latex agglutination test (LAT).

Latex antigen preparation: The antigen prepared through sensitization of latex particles with locally isolated T. gondii strain sonicated tachyzoites as procedures of Lunde and Jacobs (1967). The test procedures were adopted as methods of Holliman et al. (1989).

(2) Indirect haemagglutination test (IHAT). Using Toxo-HAI Fumouze kit (Fumouze, France). Procedure was done according to the manufacturer's instructions, according to (Camargo and Leser, (1976).

(3) Enzyme linked immunosorbent assay (ELISA). According to Voller et al. (1976) .

Antigen preparation: It was kindly obtained from Zoonotic Diseases Department, Veterinary Research Division, National Research Centre, El-dokki, Giza, Egypt). Whole soluble tachyzoites antigens were prepared as described by Waltman et al. (1984).

The technique was performed as previously described by Voller et al. (1976). In brief, ELISA plates were coated over night at $4^{\circ} \mathrm{C}$ with $10 \mu \mathrm{g} / \mathrm{ml}$ of $T$. gondii antigen diluted in carbonate-bicarbonate buffer $(0.1 \mathrm{M}, \mathrm{pH} 9.6,100 \mu \mathrm{l} /$ well). The plates were washed three times with $0.05 \%$ PBS-Tween 20 (PBS-T) and blocked by addition of 100 $\mu 1 /$ well bovine serum albumin in PBS for one hour at $37^{\circ} \mathrm{C}$. After repeated washing, $100 \mu \mathrm{l} /$ well of duplicate dilution of sera (positive, negative or tested serum sample) [Sera diluted 1:100 in PBS-T] was added per well and incubated for one hour at $37^{\circ} \mathrm{C}$. The sera were removed by repeated washing and $100 \mu \mathrm{l} /$ well of conjugate, which was antisheep/ anti-horse IgG horseradish peroxidase enzyme conjugated then incubated for one hour at $37^{\circ} \mathrm{C}$. After three washings of the plates with PBS-T, $100 \mu \mathrm{l} /$ well of pnitrophenyl phosphate in substrate buffer were added and re-incubated for one hour at $37^{\circ} \mathrm{C}$. Stopping the reaction was done parallel for the tested sera. Results were expressed as OD and the positive threshold value was determined to be equal to the mean of the negative control sera value + two folds the standard deviation.

\section{Statistical analysis:}

The obtained data were computed and analyzed by using repeated measures ANOVA and the results were tested for significance using t-test (SAS, 1996). To identify risk factors associated with infection by $T$. gondii, a bivariate analysis was carried out using Chisquare and Fisher's exact tests with significance level of $5 \%$, using the statistical program EPI-INFO, version 3.5.1. 


\section{RESULTS}

\section{1 - Seroprevalence rate of toxoplasmosis:}

Seroprevalence rate of toxoplasmosis were $41.7 \%$, $66.1 \%$ and $62 \%$ in sheep, $49.4 \%, 64.2 \%$ and $50.6 \%$ in goat, $50 \%, 72.2 \%$ and $72.2 \%$ in horse and $44.3 \%$, $67.1 \%$ and $68.4 \%$ in donkeys, by LAT; IHAT and ELISA respectively (Table 1). The peak levels of IHAT titers in both sheep and goats was >1:1280, whereas in horses and donkeys was 1:160.

\section{2 - Bioassay in cats}

The results of tissues bioassay in cats revealed that 8 out of 25 slaughtered sheep $(32.0 \%)$ and 9 out of 25 slaughtered donkeys $(36.0 \%)$ were positive (Table 2 ). Oocysts of $T$. gondii were observed after a prepatent period (P.P.P.) $3-4$ days. The cats continued shedding toxoplasma oocysts for $9-13$ days from the appearance of oocysts (Picture 1).

Table 1: Seroprevalence of toxoplasmosis in sheep, goats, horses and donkeys using LAT, IHAT and ELISA tests.

\begin{tabular}{|c|c|c|c|c|c|c|c|c|c|}
\hline \multirow{3}{*}{\multicolumn{2}{|c|}{ Species }} & \multirow{3}{*}{$\begin{array}{l}\text { Total } \\
\text { No. }\end{array}$} & \multicolumn{7}{|c|}{ Serological tests } \\
\hline & & & \multicolumn{2}{|c|}{ LAT } & \multicolumn{2}{|c|}{ IHA } & \multicolumn{2}{|c|}{ ELISA } & \multirow{2}{*}{$\begin{array}{c}\text { P- } \\
\text { value }\end{array}$} \\
\hline & & & $+\mathbf{v e}$ & $\%$ & $+\mathrm{ve}$ & $\%$ & $+\mathrm{ve}$ & $\%$ & \\
\hline \multirow{3}{*}{$\begin{array}{c}\text { Small } \\
\text { ruminants }\end{array}$} & Sheep & 292 & 122 & 41.7 & 193 & 66.1 & 181 & 62.0 & 0.023 \\
\hline & Goats & 81 & 40 & 49.4 & 52 & 64.2 & 41 & 50.6 & \\
\hline & Total & 373 & 162 & 43.4 & 245 & 65.7 & 222 & 60.0 & \\
\hline \multirow{3}{*}{ Equine } & Horses & 54 & 27 & 50 & 39 & 72.2 & 39 & 72.2 & $<0.000$ \\
\hline & Donkeys & 79 & 35 & 44.3 & 53 & 67.1 & 54 & 68.4 & 0.013 \\
\hline & Total & 133 & 62 & 46.6 & 92 & 69.2 & 93 & 69.9 & \\
\hline
\end{tabular}

\section{Histopathological examination}

Histopathological examination of bioassay positive diaphragm muscles revealed $T$. gondii tissue cysts in only $3(37.5 \%)$ sheep samples and 4 (44.4\%), donkeys samples (Picture 2).

\section{Sensitivity and specificity of different serological tests in relation to bioassay in cats}

The comparison between results of serological tests and results of bioassay in cats, the sensitivity of LAT, IHAT and ELISA were $87.5 \%, 100 \%$ and $100 \%$ in sheep respectively and $55.7 \%, 88.9 \%$ and $100 \%$ in donkeys respectively, while the specificity of LAT, IHAT and ELISA were $76.5 \%, 100 \%$ and $100 \%$ in sheep respectively and $93.8 \%, 93.8 \%$ and $100 \%$ in donkeys respectively (Table 2 ).

5. Risk factors associated with the infection with $\mathbf{T}$. gondii in sheep, goats, horses and donkeys in sheep, goats, horses and donkeys:

a. Host: The seropositivty of toxoplasmosis by ELISA was higher in equine (horses $72.2 \%$ and donkeys, $68.4 \%$ ) than in small ruminants (sheep, 62.0\% and goats, $50.6 \%$ ). There was a highly significant differences in $\mathrm{T}$. gondii infection among animal species, seropositivity in horses was 4.88 times ( $\mathrm{P}$. value $<0.000)$, in donkeys was 2.54 times $(\mathrm{p}=0.013)$ and in sheep was $1.8(\mathrm{p}=0.023)$ higher than was in goats.

b. Gender: $T$. gondii infection was significantly higher $(\mathrm{P}$ - value $<0.01)$ in female sheep $(67.3 \%)$, goats $(62.5 \%)$, horses $(80.0 \%)$ and donkeys $(90.3 \%)$ than in male sheep $(48.8 \%)$, goats $(24.0 \%)$, horses $(57.9 \%)$ and donkeys $(73.9 \%)$.

c. Age: Toxoplasmosis in small ruminants (sheep and goats) and equine (horses and donkeys) was significantly higher $(\mathrm{P}-$ value $<0.05)$ at age $>5$ years in sheep $(80.7 \%)$ [OR $=17.5]$, goats $(66.7 \%)[\mathrm{OR}=6]$, horses $(89.5 \%)$ [OR $=13]$ and donkeys $(83.7 \%)$ [OR $=18]$ than that at age $<2$ year sheep $(41.6 \%)$, goats $(31.3 \%)$, horses $(50.0 \%)$ and donkeys $(30.8 \%)$.

d. Abortion: There was non-significant increase (p. value $>0.05)$ in incidence of toxoplasmosis in aborted ewes $15 / 17(88.2 \%)$ [OR= 1.22] and goats $5 / 6$ $(83.3 \%)$ [OR=3.33] than those with normal birth $92 / 153(60.1 \%)$ and $21 / 35(60.0 \%)$ in ewes and goats respectively, While in equine, toxoplasmosis in both aborted mares and she-donkeys $(75 \%)$ was less than in normally birthing mares $(79.17 \%)$ $[\mathrm{OR}=0.79]$ and she-donkeys $(86.9 \%)$ [OR=0.43]. 
e. Rearing system: Toxoplasmosis was highly significantly increased in sheep and goats which raised in intensive management system $(76.4 \%$ $\$ 56.8 \%)$ [P- value, < 0.01$]$ than those raised in extensive $(46.5 \% \quad \& \quad 33.3 \%)$ and semi-intensive system (62.1\% \& 46.4\%). Moreover sheep \& goats reared under intensive system were 2.6 times more likely to have toxoplasmosis than those reared under extensive system [Table 3].

Table 2: Showing sensitivity and specificity of LAT, IHAT and ELISA in slaughtered sheep and donkeys using tissues bioassay in cats as a gold standard test.

\begin{tabular}{|c|c|c|c|c|c|}
\hline \multirow{2}{*}{ Species } & \multirow{2}{*}{$\begin{array}{l}\text { Serological } \\
\text { tests }\end{array}$} & \multirow{2}{*}{ Data } & \multicolumn{3}{|c|}{ Tissues Bioassay in cats } \\
\hline & & & +ve No. & -ve No. & Total \\
\hline \multirow{15}{*}{ Sheep } & \multirow{5}{*}{ LAT } & Positive & 7 & 4 & 11 \\
\hline & & Negative & 1 & 13 & 14 \\
\hline & & Total & 8 & 17 & 25 \\
\hline & & Sensitivity & \multicolumn{3}{|c|}{$87.50 \%$} \\
\hline & & Specificity & \multicolumn{3}{|c|}{$76.50 \%$} \\
\hline & \multirow{5}{*}{ IHAT } & Positive & 8 & 0 & 8 \\
\hline & & Negative & 0 & 17 & 17 \\
\hline & & Total & 8 & 17 & 25 \\
\hline & & Sensitivity & \multicolumn{3}{|c|}{$100 \%$} \\
\hline & & Specificity & \multicolumn{3}{|c|}{$100 \%$} \\
\hline & \multirow{5}{*}{ ELISA } & Positive & 8 & 0 & 8 \\
\hline & & Negative & 0 & 17 & 17 \\
\hline & & Total & 8 & 17 & 25 \\
\hline & & Sensitivity & \multicolumn{3}{|c|}{$100 \%$} \\
\hline & & Specificity & \multicolumn{3}{|c|}{$100 \%$} \\
\hline \multirow{15}{*}{ Donkeys } & \multirow{5}{*}{ LAT } & Positive & 5 & 1 & 6 \\
\hline & & Negative & 4 & 15 & 19 \\
\hline & & Total & 9 & 16 & 25 \\
\hline & & Sensitivity & \multicolumn{3}{|c|}{$55.7 \%$} \\
\hline & & Specificity & \multicolumn{3}{|c|}{$93.8 \%$} \\
\hline & \multirow{5}{*}{ IHAT } & Positive & 8 & 1 & 9 \\
\hline & & Negative & 1 & 15 & 16 \\
\hline & & Total & 9 & 16 & 25 \\
\hline & & Sensitivity & \multicolumn{3}{|c|}{$88.9 \%$} \\
\hline & & Specificity & \multicolumn{3}{|c|}{$93.8 \%$} \\
\hline & \multirow{5}{*}{ ELISA } & Positive & 9 & 0 & 9 \\
\hline & & Negative & 0 & 16 & 16 \\
\hline & & Total & 9 & 16 & 25 \\
\hline & & Sensitivity & \multicolumn{3}{|c|}{$100 \%$} \\
\hline & & Specificity & \multicolumn{3}{|c|}{$100 \%$} \\
\hline
\end{tabular}


Assiut Vet. Med. J. Vol. 61 No. 145 April 2015

Table 3: Showing some risk factors related to toxoplasmosis in small ruminants (sheep and goats) and equine (horses and donkeys).

\begin{tabular}{|c|c|c|c|c|c|c|c|c|c|c|c|c|c|c|c|c|c|c|c|c|c|}
\hline \multirow{3}{*}{\multicolumn{2}{|c|}{ Risk Factors }} & \multicolumn{5}{|c|}{ Sheep } & \multicolumn{6}{|c|}{ Goats } & \multicolumn{5}{|c|}{ Horses } & \multicolumn{4}{|c|}{ Donkeys } \\
\hline & & \multirow[b]{2}{*}{$\begin{array}{l}\text { Totel } \\
\text { № }\end{array}$} & \multirow[b]{2}{*}{ twe } & \multirow[b]{2}{*}{$\%$} & \multirow{2}{*}{$\begin{array}{c}\text { OR } \\
(95 \% \\
\text { CI })\end{array}$} & \multirow[b]{2}{*}{ Pralue } & \multirow[b]{2}{*}{$\begin{array}{l}\text { Total } \\
\text { No }\end{array}$} & \multirow[b]{2}{*}{ the } & \multirow[b]{2}{*}{$\%$} & \multirow{2}{*}{$\begin{array}{c}\text { OR } \\
(95 \% \\
\text { CI })\end{array}$} & \multirow[b]{2}{*}{ Pralue } & \multirow[b]{2}{*}{$\begin{array}{l}\text { Total } \\
\text { Na }\end{array}$} & \multirow[b]{2}{*}{ the } & \multirow[b]{2}{*}{$\%$} & \multirow{2}{*}{$\begin{array}{c}\text { OR } \\
(95 \% \\
\text { CI })\end{array}$} & \multirow[b]{2}{*}{ P-vahe } & \multirow[b]{2}{*}{$\begin{array}{l}\text { Tod } \\
\text { Na }\end{array}$} & \multirow[b]{2}{*}{ the } & \multirow[b]{2}{*}{$\%$} & \multirow{2}{*}{$\begin{array}{c}\text { OR } \\
(95 \% \\
\text { CI })\end{array}$} & \multirow[b]{2}{*}{ Prahte } \\
\hline & & & & & & & & & & & & & & & & & & & & & \\
\hline & ecies & 292 & 181 & 61.9 & 1.8 & 0.023 & 81 & 41 & 50.6 & 1 & & 54 & 39 & 72.2 & $\begin{array}{c}4.88(2.11 \\
-11.28\end{array}$ & $\varangle 0.000$ & 79 & 54 & 68.4 & $\begin{array}{l}2.54 \\
(1.2- \\
5.3)\end{array}$ & 0.013 \\
\hline \multirow[t]{2}{*}{ Sex } & Male & 84 & 41 & 48.8 & 1 & \multirow[b]{2}{*}{0.0133} & 25 & 6 & 24 & 1 & \multirow[b]{2}{*}{0.0022} & 19 & 11 & 57.9 & 1 & 0.0012 & 35 & 20 & 73.9 & 1 & \\
\hline & Female & 208 & 140 & 67.3 & $\begin{array}{c}2.01 \\
(1.16-3.50)\end{array}$ & & 56 & 35 & 62.5 & $\begin{array}{c}5.28 \\
(1.82- \\
15.32)\end{array}$ & & 35 & 28 & 80 & $\begin{array}{c}2.91(0.85 \\
-9.96)\end{array}$ & & 44 & 34 & 90.3 & $\begin{array}{l}329 \\
(0.73- \\
1493)\end{array}$ & 0.0013 \\
\hline Age & $\leq 2 \mathrm{Y}$ & 89 & 37 & 41.6 & 1 & 0.121 & 32 & 10 & 31.3 & 1 & 0.556 & 14 & 7 & 50 & 1 & & 13 & 4 & 30.8 & 1 & \\
\hline & $>2-5 \mathrm{Y}$ & 146 & 98 & 67.1 & $\begin{array}{c}5.71 \\
(2.07- \\
15.75)\end{array}$ & 0.001 & 37 & 23 & 62.2 & $\begin{array}{l}4.93 \\
(1.14- \\
21.35)\end{array}$ & 0.033 & 21 & 15 & 71.4 & $\begin{array}{c}2.5(0.61- \\
10.26)\end{array}$ & 0.203 & 23 & 14 & 60.9 & $\begin{array}{l}4.13 \\
(0.49- \\
3450)\end{array}$ & 0.039 \\
\hline & $\geq 5 \mathrm{Y}$ & 57 & 46 & 80.7 & $\begin{array}{c}17.5 \\
(4.89- \\
62.69)\end{array}$ & $<0.000$ & 12 & 8 & 66.7 & $\begin{array}{c}6 \\
(1.02- \\
35.37)\end{array}$ & 0.048 & 19 & 17 & 89.5 & $\begin{array}{l}13(132- \\
128.11)\end{array}$ & 0.028 & 43 & 36 & 83.7 & $\begin{array}{l}18(1.19 \\
27146)\end{array}$ & 0.013 \\
\hline & $\begin{array}{c}\text { Normal } \\
\text { birth }\end{array}$ & 153 & 92 & 60.1 & 1 & & 35 & 21 & 60 & 1 & & 24 & 19 & 79.2 & 1 & & 23 & 20 & 86.9 & 1 & \\
\hline 䒿 & $\begin{array}{c}\text { Previously } \\
\text { aborted }\end{array}$ & 17 & 15 & 88.2 & $\begin{array}{l}1.22 \\
(0.25- \\
5.90)\end{array}$ & 0.8 & 6 & 5 & 83.3 & $\begin{array}{l}3.33 \\
(0.35- \\
31.66)\end{array}$ & 0.29 & 4 & 3 & 75 & $\begin{array}{c}0.79 \\
(0.07- \\
9.32)\end{array}$ & 0.85 & 4 & 3 & 75 & $\begin{array}{c}0.43 \\
(0.03- \\
5.58)\end{array}$ & 0.52 \\
\hline & Extensive & 99 & 46 & 46.5 & 1 & & 9 & 3 & 33.3 & 1 & & & & & & & & & & & \\
\hline 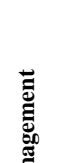 & $\begin{array}{c}\text { Semi- } \\
\text { intensive }\end{array}$ & 87 & 54 & 62.1 & $\begin{array}{l}(0.74 \\
2.54)\end{array}$ & 0.324 & 28 & 13 & 46.4 & $\begin{array}{c}(0.36- \\
8.35)\end{array}$ & 0.493 & & & & & & & & & & \\
\hline$\Sigma$ & & & & & 2.59 & & & & & 2.63 & & & & & & & & & & & \\
\hline & Intensive & 106 & 81 & 76.4 & $\begin{array}{l}(1.38- \\
4.85)\end{array}$ & 0.003 & 44 & 25 & 56.8 & $\begin{array}{l}(058- \\
11.90)\end{array}$ & 0.209 & & & & & & & & & & \\
\hline
\end{tabular}




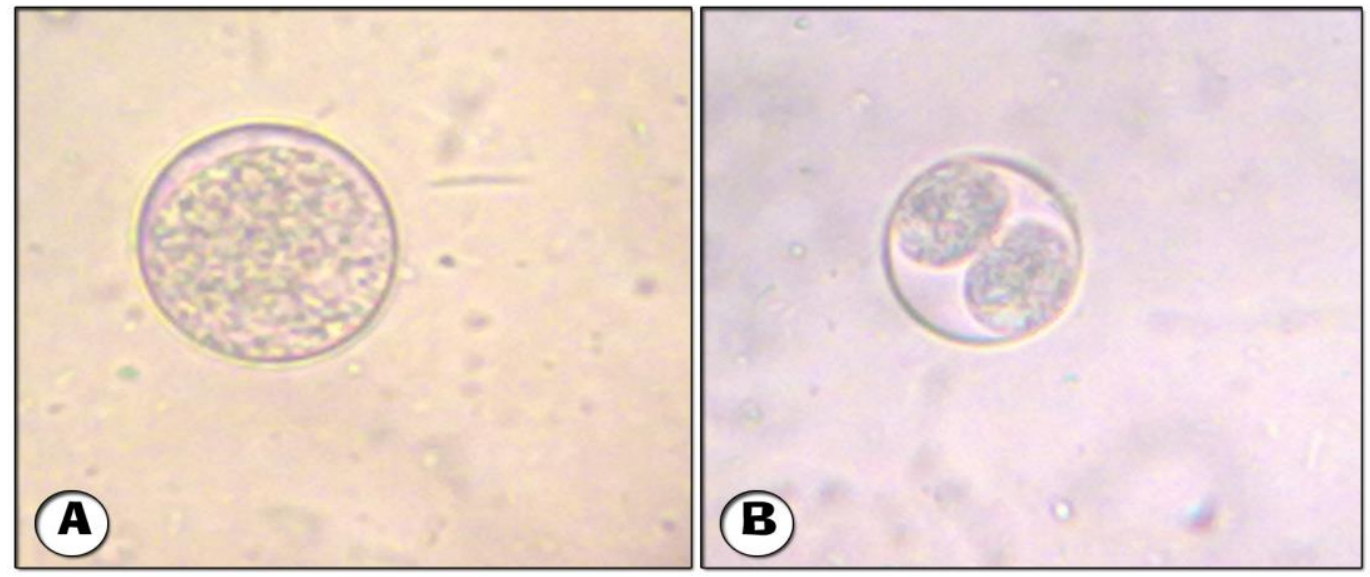

Picture (1): Toxoplasma gondii non sporulated oocysts. (A) and T. gondii sporulated oocysts (B). X 1200

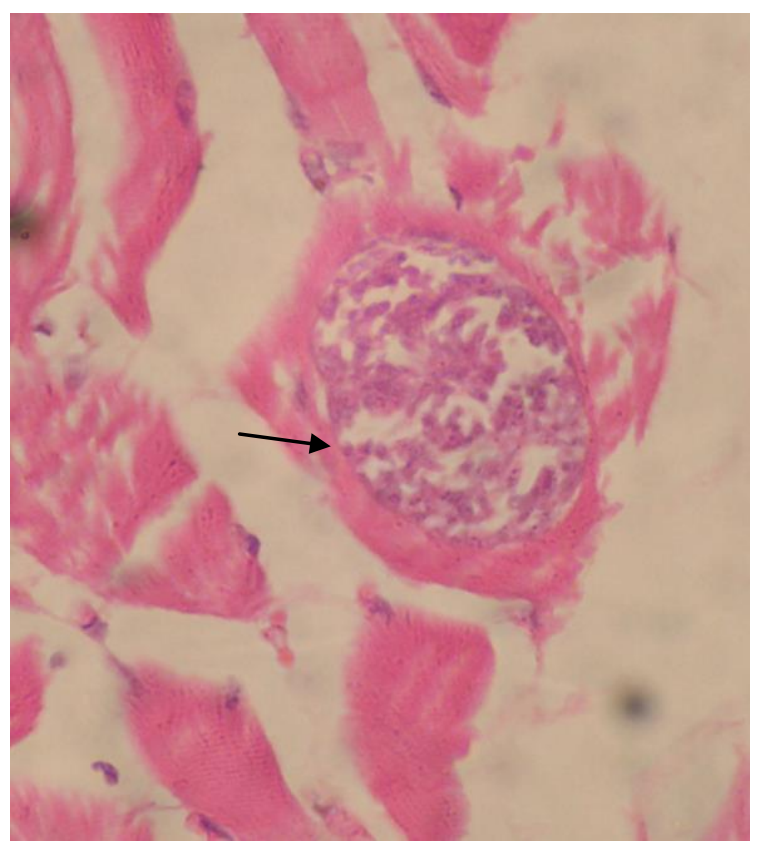

Picture (2): photomicrograph from diaphragm muscle of sheep showing $T$. gondii tissue cyst (arrow) $\{\mathrm{H} \mathrm{\&} \mathrm{E} . \mathrm{X}$ 1200\}.

\section{DISCUSSION}

Toxoplasmosis has a very wide geographic distribution and is considered to be one of the most common parasitic infections of man and warm blooded animals. Clinical symptoms of toxoplasmosis are not specific. Therefore, evaluation of serological tests becomes important in order to use sensitive and specific tests in serological surveys (Uggla et al., 1983 and Moreno et al., 1991).

With regard to the seroprevalence of toxoplasmosis, $122(41.7 \%), 193(66.1 \%)$ and $181(62.0 \%)$ out of 292 sheep, $40(49.4 \%), 52(64.2 \%)$ and $41(50.6 \%)$ out of 81 goats, $27(50.0 \%), 39(72.2 \%)$ and 39 (72.2\%) out of 54 horses and 35 (44.3\%), 53 (67.1\%) and $54(68.4 \%)$ out of 79 donkeys were sero-positive against toxoplasmosis by LAT; IHAT and ELISA respectively. The difference in antibody response observed by use of the three serological tests may be in part due to the type of antigen used and in other part due to the class of antibodies measured. These results were concordant with those reported by Shaapan (2005) who found that the seroprevalence of toxoplasmosis in slaughtered sheep were $34 \%$ by DT, $37 \%$ by IFAT, $41.7 \%$ by ELISA and $43.7 \%$ by MAT. 
High seroprevalence of toxoplasmosis among sheep seems to be catches with those reported previously where $51.5 \%$ in Brazil by IFAT (Romanelli et al., 2007); $50.4 \%$ and $61.4 \%$ in Egypt by LAT and ELISA respectively (Hassanain et al., 2011); $71 \%$ in Libya by LAT (Al-mabruk et al., 2013) and 67\% in the Caribbean Dominica Island by ELISA (Hamilton et al., 2014). In goats our results were nearly similar to those obtained by several authors where $46.0 \%$ in Brazil by IFAT (Carneiro et al., 2009); 50\% in Turkey by IHAT (Sevinc et al., 2000a) and $52.8 \%$ in Romania by ELISA (Iovu et al., 2012). Moreover in equine similar results were described where $65.3 \%$ of donkeys from Monofia province, Egypt by ELISA (El-Ghaysh, 1998); 71.2\% of horses in Iran by MAT (Hajialilo et al., 2010).

On the other hand, lower and higher seroprevalence of toxoplasmosis in sheep were observed elsewhere; for examples, $95.7 \%$ and $90.9 \%$ in Kars province, Turkey by ELISA and SFDT respectively (Mor and Arslan, 2007); $34.5 \%$ in Somalia by LAT (Kadle, 2014); $29.9 \%$ in Mexico by MAT (Alvarado-Esquivel et al., 2013) and $3.3 \%$ in Iran by IFAT (Derakhshan and Mousavi 2014). In goats lower seroprevalence of toxoplasmosis were reported by Figueiredo et al. (2001) in Brazil $18.4 \%$ by IHAT; Kandil and Abou-Zeina (2000) in Egypt $39 \%$ by ELISA and Derakhshan and Mousavi (2014) in Iran $1.7 \%$ by IFAT, whereas higher results were reprted by Beyhan et al. (2013) in Turkey $95.24 \%$ by (SFDT), Also variable seroprevalence of toxoplasmosis in equines, were observed elsewhere; for examples, $6.9 \%$ of horses in North America (MAT) (Dubey et al., 1999), 7.2\% of horses in Turkey (SFDT) (Karatepe et al., 2010); 25\% of horses and $23.6 \%$ of donkeys in China by MAT (Yang et al., 2013); and 5\% and 8\% of donkeys in Italy by LAT and IFAT (Machacova et al., 2014). The difference in seroprevalence rates in the present work and the previous studies may be also attributed to abundance of infected cats and their contact with examined animals in farms and slaughtered houses.

With regard to tissue bioassays in cats the results revealed T. gondii from $32.0 \%$ \& $36.0 \%$ of slaughtered sheep and donkeys. These results were in agreement with Esteban-Redondo et al. (1999) and Da Silva and Langoni, (2001). Also Shaapan and Ghazy, (2007) found that $52.6 \%$ of horses were T. gondii infected by bioassays in mice and cats.

Results of histopathological examination of diaphragm of sheep and donkeys, which positive by tissues bioassay in cats, revealed $T$. gondii tissue cysts in only 3out of $8(37.5 \%)$ and 4 out of 9 (44.4\%), respectively. These results were in agreement with those recorded by Belbacha et al. (2004) and Hassanain et al. (2011).

The comparison between results of serological tests and results bioassay in cats, the sensitivity of both ELISA and IHAT in sheep and donkeys were $100 \%$, whereas sensitivity of LAT was $87.5 \%$ and $55.7 \%$ in sheep and donkeys. Also specificity of ELISA in sheep and donkey were $100 \%$, while specificity of IHAT and LAT were $100 \% \& 76.5 \%$ in sheep and were $93.8 \%$ \& $93.8 \%$ in donkey. These results coincided with those detected by Figueiredo et al. (2001) who reported that there was a high and significant positive correlation between IHAT versus IFAT, IHAT versus ELISA, and ELISA versus IFAT; Mcload and Remington, (1996) and Puije et al. (2000), who reported that ELISA was highly sensitive $92 \%$ and specific $91 \%$ when compared to IFAT which was used as reference.

With regard to species susceptibility, the seropositivty of toxoplasmosis by ELISA was higher in equine (horses $72.2 \%$ and donkeys, 68.4\%) than in small ruminants (sheep, $62.0 \%$ and goats, 50.6\%). The higher percentage of infection in equine may be attributed to the old infections of examined animals, where the peak levels of IHAT titers in horses and donkeys was 1:160 and was $>1: 1280$ in both sheep and goats. These results were in agreement with those reported by Puije et al. (2000) in Ghana 32.2\% \& $26.8 \%$ of sheep \& goats by ELISA and Ahmed et al. (2013) in Sudan $38 \%$ and $27.6 \%$ of horses and donkeys respectively by LAT. This result differs from those reported by Gondim et al. (1999) in Brazil $28.93 \%$ and $18.75 \%$ in goats and sheep by LAT; Prelezov et al. (2008) in Bulgaria $48.2 \%$ \& $59.8 \%$ of sheep and of goats by IHAT and Bocanegra et al. (2012) in Spain $10.8 \%$ \& $25.6 \%$ of horses and donkeys by MAT. This variation in species susceptibility may be attributed to difference on the environmental and ecological condition, which effect on the biology of the parasite or the system of breeding and hygienic measures inside farms.

With regard to gender, T. gondii infection was significantly higher $(\mathrm{P}$ - value $<0.01)$ in female sheep $(67.3 \%)$, goats $(62.5 \%)$, horses $(80.0 \%)$ and donkeys $(90.3 \%)$ than in male sheep $(48.8 \%)$, goats $(24.0 \%)$, horses $(57.9 \%)$ and donkeys $(73.9 \%)$. These were in agreement with those reported by Hajialilo et al. (2010); Al-mabruk et al. (2013); and Dubey et al. (2014). These results were not coincided with Esmat, (1997) and Boughattass et al. (2011). This variation may be attributed to the young age of male sheep and goats used in this study.

With regard to age susceptibility, toxoplasmosis was significantly higher $(\mathrm{P}$ - value $<0.05)$ in sheep, goats, horses and donkeys at age $>5$ years than that at age $<1$ year. This variation may be due to the exposure of old animals to $T$. gondii oocysts for long periods. These results were in agreement with those observed by Figueiredo et al. (2001); Boughattass et al. (2011) and Al-mabruk et al. (2013).

Moreover toxoplasmosis was significantly higher in sheep and goats which raised in intensive management system $(76.4 \% \quad \& 56.8 \%)$ than those 
raised in extensive $(46.5 \%$ \& $33.3 \%)$ and semiintensive system $(62.1 \% \& 46.4 \%)$. This variation may be related presence of uncontrolled number of stray cats around farms. These results coincided with those recorded by Neto et al. (2008); Tzanidakis et al. (2012) and Al-mabruk et al. (2013).

Toxoplasmosis was highly significantly increased in aborted sheep 15/17 (88.2\%) and 5/6 (83.3\%) goats than those with normal birth $92 / 153(60.1 \%)$ and $21 / 35$ $(60.0 \%)$ respectively. These differences may be due to multiplication of T.gondii in placenta and release of antigen into maternal circulation. These results were in agreement with those reported by Aktas et al. (2000); Sevinc et al. (2000 b) and Hussein et al. (2011).

It could be concluded that IHAT in sheep, goats, horses and donkeys could be used as a screening test in seroepidemiological studies, and their results must be confirmed by ELISA. Species, gender, age, rearing system play an important role in incidence of toxoplasmosis. Seroprevalence of $T$. gondii infection indicated wide spread of toxoplasmosis in sheep, goats, horses and donkeys in Dakahlia province. Thus further studies will be needed to clarify the role of sheep, goats, horses and donkeys in transmission of infection to man and pet animals.

\section{ACKNOWLEDGEMENTS}

The authors are deeply indebted to Dr. Raafat $M$. Shaapan, Prof. of zoonotic Diseases, Veterinary Research Division, National Research Center, for providing $T$. gondii strain used, antigen preparation for LAT and ELISA. Also, the authors are thankful to Mohamed Afifi (Biostatistics Assistant Lecturer) faculty of Veterinary Medicine, Zagazig University, for his valuable assistance in performing the statistical analysis.

\section{REFERENCES}

Ahmed, S.M.; Ibrahim, A.M.; Alshafie, N.K.; Rabab, H.M.; Ismail, A.A. and Tamador, E.E. (2013): The First Report on Sero-Prevalence of Toxoplasma gondii in Working Horses and Donkeys in the Sudan. Journal of Life Sciences, 7(12): 1284-1287.

Aktas, M.; Babur, C. and Duzgun, A. (2000): Seroprevalence of $T$. gondii in sheep in MalatyaTurkey. Saglik-Bilimleri-Dergisi, 14 (1): 65-67.

Al-mabruk, A.A.; Somia, R.A.; El-Buni, A.A.; Annajar, B.B. and Elsaid, M.M.A. (2013): Seroprevalence of Toxoplasma gondii antibodies in sheep from Libya. International Journal of Advanced Research, 1(9): 148-154.

Alvarado-Esquivel, C.; Aguilarb, D.S.; Isabelle, V. and Dubey, J.P. (2013): Seroprevalence and correlates of Toxoplasma gondii infection in domestic sheep in Michoacán State, Mexico.
Preventive Veterinary Medicine, 112: 433-437.

Bancroft, J.D. and Stevens, A. (1996): Theory and practice of hisotological. Techniques. 4th Ed. Churchill, Livingston, Edinburgh, London, Melbourne and New York.

Belbacha, I.; Hafid, J.; Tran Manh Sung, R.; Flori, P.; Raberin, H.; Aboufatima, R.; Regragui, A.; Dalal, A. and Chait, A. (2004): Toxoplasma gondii: level of carriage in sheep of Marrakech region (Mnabha). Schweiz Arch Tierheilkd. 146 (12): 561-4.

Bocanegra, G.; Cabezon, O.; Montes, A.A.; Carbonero, A.; Dubey, J.P.; Almeria, S. and Perea, A. (2012): Seroprevalence of Toxoplasma gondii in equids from Southern Spain. Parasitology International; 61: 421-424.

Boughattass, S.; Bergaoui, R.; Rym, E.; Aoun, K. and Aida, B. (2011): Seroprevalence of Toxoplasma gondii infection among horses in Tunisia. Parasites \& Vectors.

Buxton, D.; Maley, S.; Wright, S.; Rodger, S.; Bartley, P. and Innes, E. (2007): Toxoplasma gondii and ovine toxoplasmosis: new aspects of an old story. Veterinary Parasitology 149, 25-28.

Beyhan, Y.E.; Babur, C.; Pekkaya, S. and Dalkilic, B. (2013): Investigation of anti-Toxoplasma gondii antibodies in goats in Kilis province. Etlik Vet Mikrobiyol Derg, 24: 17-19.

Camargo, M.E. and leser, P.G. (1976): Diagnostic information from serological tests in human toxoplasmosis, II: Evaluated study of antibodies and serological pattern on acquired toxoplasmosis as detected by haemagglutination and compliment fixation. Rev. Inst. Med. Trop. Saopaulo, Brazil, 18:277.

Carneiro, A.C.A.V.; Carneiro, M.; Gouveia, A.M.G.; Guimaraes, A.S.; Marques, A.P.R.; VilasBoas, L.S. and Vitor, R.W.A. (2009): Seroprevalence and risk factors of caprine toxoplasmosis in Minas Gerais, Brazil. Veterinary Parasitology, 160: 225-229.

Da Silva, A.V. and Langoni, H. (2001): The detection of Toxoplasma gondii by comparing cytology, histopathology, bioassay in mice, and the polymerase chain reaction. Vet. Parasitol. 97(3): 191-8.

Derakhshan, M. and Mousavi, M. (2014): Serological survey of antibodies to Toxoplasma gondii in cats, goats, and sheep in Kerman, Iran. Comparative Clinical Pathology, 23(2): 267-268.

Dubey, J.P. (2001): Oocyst shedding by cats fed isolated bradyzoites and comparison of infectivity of bradyzoites of the VEG strain Toxoplasma gondii to cats and mice. Journal of Parasitology 87, 215-219. 
Dubey, J.P. (2010): Toxoplasmosis of animals and humans. Second edition. Boca Raton, FL: CRC Press;. 313 pp.

Dubey, J.P. and Beattie, C.P. (1988): Toxoplasmosis of Animals and Man.Boca Raton, FL: CRC Press; pp. 1-220.

Dubey, J.P.; Ness, S.L.; Kwok, O.C.H.; Choudhary, S.; Mittel, L.D. and Divers, T.J. (2014): Seropositivity of Toxoplasma gondii in domestic donkeys (Equus asinus) and isolation of $T$. gondii from farm cats. Veterinary Parasitology, 199 (1-2): 18-23.

Dubey, J.P.; Speer, C.A. and Fayer, R. (1989): Sarcocystosis of animals and man. CRC Press, Boca Raton, Florida, 1-215.

Dubey, J.P.; Thulliez, P.; Roman, S.; Kwok, O.C.H.; Shen, S.K. and Gamble, H.R. (1999): Serologic prevalence of Toxoplasma gondii in horses slaughtered for food in North America. Vet. Parasitol, 86, 235-238.

El-Ghaysh, A. (1998): Seroprevalence of Toxoplasma gondiiin Egyptian donkeys using ELISA. Vet Parasitol, 80, 71-73.

El-On, J. and Peiser, J. (2003): Toxoplasma and toxoplasmosis. Harefuah 142 (1): 48-55.

Esmat, M. (1997): Seroprevalence of toxoplasmosis in sheep and goats. 4th Sci. Cong. Egyptian Society for Cattle Diseases, 7-9 Dec. 1997, Assiut, Egypt.

Esteban-Redondo, I.; Maley, S.W.; Thomson, K.; Nicoll, S.; Wright, S.; Buxton, D. and Innes, E.A. (1999): Detection of T. gondii in tissues of sheep and cattle following oral infection. Vet. Parasitol. 86(3): 155-71.

Figueiredo, J.F.; Silva, D.A.O.; Cabral, D.D. and Mineo, J.R. (2001): Seroprevalence of Toxoplasma gondii infection in gotas by the indirect haemagglutination, immunofluorescence and immunoenzymatic tests in the region of Uberlandia, Brazil. Memorias do Instituto Oswaldo Cruz. 96: 5, 687-692.

Gondim, L.F.; Barbosa, H.V.; Filho, C.H. and Saeki, H. (1999): Serological survey of antibodies to Toxoplasma gondii in goats, sheep, cattle and water buffaloes in Bahia State, Brazil. Vet. Parasitol. 82 (4): 273-6.

Hajialilo, E.; Ziaali, N.; Harandi, M.F.; Saraei, M. and Hajialilo, M. (2010): Prevalence of antiToxoplasma gondii antibodies in sport horses from Qazvin, Iran. Trop Anim Health Prod, 42, 1321-1322.

Hamilton, C.M.; Katzer, F.; Innes, E.A. and Kelly, P.J. (2014): Seroprevalence of Toxoplasma gondii in small ruminants from four Caribbean islands. Parasites \& Vectors, 7: 449

Hassanain, M.A.; Elfadaly, H.A.; Shaapan, R.M.; Hassanain, N.A. and Barakat, A.M. (2011): Biological Assay of Toxoplasma gondii Egyptian Mutton Isolates. International Journal of Zoologicl Research, 7 (4): 330-337.
Holliman, R.E.; Johnson, J.; Duffy, K. and New, L. (1989): Discrepant toxoplasma latex agglutination test results. J. Clin Pathol 42, 200-203.

Hussein, M.F.; Al-Mufarrej, S.I.; Al-Jumaah, R.S.; Al-Saiady, M.Y.; Gar-Elnabi, A.R. and AbuZaid, T.S. (2011): Serological prevalence of Toxoplasma gondii and its association with abortion in sheep in Saudia Arabia. ActaVeterinaria (Beograd), Vol. 61, No.4, 405-414.

Iovu, A.; Györke, A.; Mircean, V.; Gavrea, R. and Cozma, V. (2012): Seroprevalence of Toxoplasma gondii and Neospora caninum in dairy goats from Romania.Veterinary Parasitology 186: 470-474.

Kadle, A.A.H. (2014): Sero-Prevalence of Toxoplasmosis in Domestic Animals in Benadir Region 'Somalia. Open Journal of Veterinary Medicine, 4: 170-174.

Kandil, O.M. and Abou-Zeina, H.A. (2000): Incidence of Toxoplasma gondii as obtained by ELISA and its impact on some hormonal changes among sheep and goats. J. Egypt. Vet. Med. Ass., 60(6): 7-14

Karatepe, B.; Babür, C.; Karatepe, M. and Kili, S. (2010): Seroprevalence of toxoplasmosis in horses in Niğde Province of Turkey. Trop Anim Health Prod, 42, 385-389.

Lunde, M.N. and Jacobs, L. (1967): Evaluation of Latex Agglutination Test for Toxoplasmosis. J. Parasitol. 53, 933-936.

Machacova, T.; Eva, B.; Loria, A.D.; Sedlak, K.; Mariani, U.; Fusco, G.; Fulgione, D.; Veneziano, V. and Dubey, J.P. (2014): Seroprevalence of Toxoplasma gondii in Donkeys (Equus asinus) in Italy. J. Vet. Med. Sci.76 (2): 265-267.

Mcload, R. and Remington, J.S. (1996): Toxoplasmosis in Nelson text book of pediatrics 15th ed. Philadelphia W.B. saunders, P. 978: 87.

Mor, N. and Arslan, M.O. (2007): Seroprevalence of Toxoplasma gondii in Sheep in Kars Province. Kafkas Üniversitesi Veteriner Fakültesi Dergisi, 13: $165-170$.

Moreno, T.; Gomz, F.M.; Rodriguez, S.H.; Cruz, M.D.M. and Moreno, A.M. (1991): The seroprevalence of ovine toxoplasmosis in Cordoba, Spina. Annuals of tropical Medicine and Parasitology, 85: 287-288.

Neto, J.; Azevedo, S.; Gennari, S., Funada, M., Pena, H., Araújo, A., Batista, C., Silva, M., Gomes, A., Piatti, R. and Alves, C. (2008): Prevalence and risk factors for anti-Toxoplasma gondii antibodies in goats of the Seridó Oriental microregion, Rio Grande do Norte state, Northeast region of Brazil. Veterinary Parasitology 156, 329-332. 
Prelezov, P.; Koinarski, V. and Georgieva, D. (2008): Seroprevalence of Toxoplasma gondii infection among sheep and goats in the Stara Zagora region. Bulgarian Journal of Veterinary Medicine, 11(2): 113-119.

Puije, W.N.A.; Bosompem, K.M.; Canaco, EA.; Wastling, JM.; Akanmori, B.D.; Vander, P. and Williams, D.L. (2000): The prevalence of anti - T. gondii antibodies in Ghanaian sheep and goats. Acta. Tropica., 76(1): 21-26.

Romanelli, P.R.; Freire, R.L.; Vidotto, O.; Marana, E.R.M.; Ogawa, L.; De Paula, V.S.O.; Garcia, J.L. and Navarro, I.T. (2007): Prevalence of Neospora caninum and Toxoplasma gondii in sheep and dogs from Guarapuava farms, Parana State, Brazil. Research in Veterinary Science, 82: 202-207.

SAS “Statistical Analysis System” (1996): SAS. User's guide: Statistic 2ndEd, Institute Inc Cary, North Carolina.

Sevinc, F.; Dik, B.; Gokcen, A.; Altinoz, F. and Uslu, $U$. (2000a): The seroprevalence of Toxoplasma gondii in goats detected by indirect haemagglutination (IHA) and indirect fluorescent antibody (IFA) tests in the region of Konya. Acta. Parasitologica. Turcica., 24: 1, 57-60; 28.

Sevinc, F.; Kamburgil, K.; Dik, B.; Guclu, F. and Aytekin, $H$. (2000b): The seroprevalence of toxoplasmosis by indirect fluorescent antibody (IFA) test in ewes with and without abortion in Konya province. Saglik Bilimleri Dergisi, Firat Universitesi. 14: 1, 137-142.

Shaapan, R.M. (2005): Studies on ovine toxoplasmosis with special respect to its control in meat. Ph.D. Thesis. Cairo University.

Shaapan, R.M. and Ghazy, A.A. (2007): Isolation of Toxoplasma gondii from horse meat in Egypt. Pak J BiolSci, 10 (1), 174-177.

Tzanidakis, N.; Maksimovb, P.; Conrathsb, F.; Kiossisc, E.; Brozosc, C.; Sotiraki, S. and Scharesb, G. (2012): Toxoplasma gondii in sheep and goats: Seroprevalence and potential risk factors under dairy husbandry practices. Veterinary Parasitology 190: 340- 34

Uggla, A.; Beskew, P.; Schwan, O.; Bergguist, N.R. and Waller, T. (1983): Ovine toxoplasmosis in Sweeden. Acta Vet. Scand., 24 (1): 113-119.

Uggla, A. and Buxton, D. (1990): Immune responses against Toxoplasma and Sarcocystis infections in ruminants: diagnosis and prospects for vaccination. Rev. sci. tech. Off. int. Epiz., 9 (2), 441-462.

Voller, A.; Bid well, D.E.; Bartlett, A.; Fleck, D.G.; Perkins, M. and Oladehin, B. (1976): A micro plate enzyme-immunoassay for Toxoplasma antibody. J. Clin. Path., 29: 150-153.

Waltman, W.D.; Dreesen, D.W.; Prickett, D.M.; Blue, J.L. and Oliver, D.G. (1984): Enzyme-linked immunosorbant assay for the detection of toxoplasmosis in swine: interpreting assay results and comparing with other serologic tests. Am. J. Vet. Res., 4.5(9) 1719-1725.

Yang, N.; Mu, M.Y.; Yuan, G.M.; Zahang, G.X.; Li, H.K. and He, J.B. (2013): Seroprevalence of Toxoplasma gondii infection in slaughtered hoses and donkeys in Liaoning Province, northeastern China. Parasit Vectors 6: 140.

\section{دراسات وبائية عن مرض التوكسوبلازما في المجترات الصغيرة والخيول بمحافظة الدقهلية ، مصر \\ عماد السبي يونس ، ناصر زيدان أبو زيا ، محد زكريا سبي أحدد ، محمود رضا محمو. \\ Email: yasserelnaker@yahoo.com \\ Assiut University Email: www.aun.edu.eg}

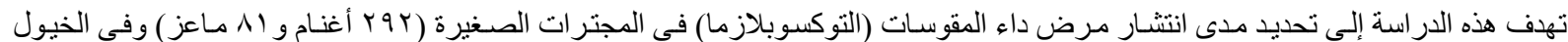

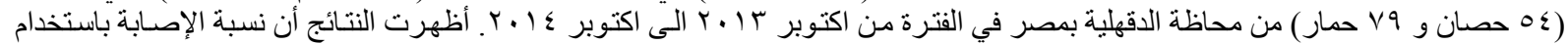

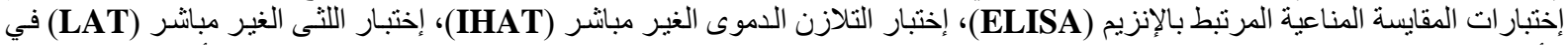

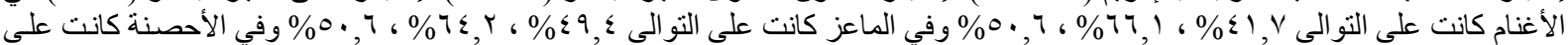

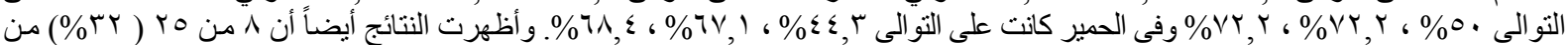

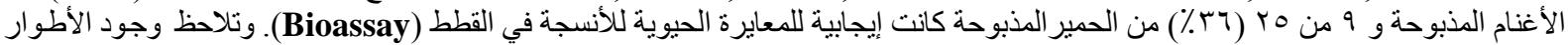

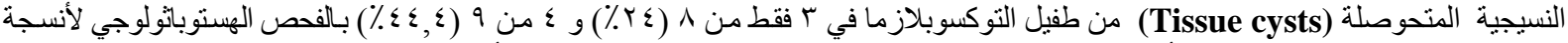

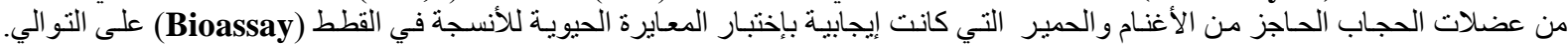

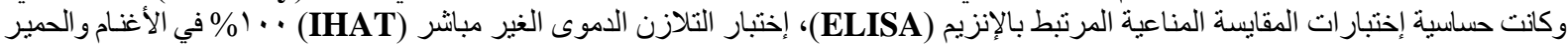

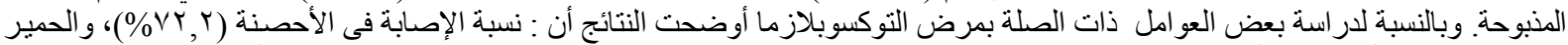

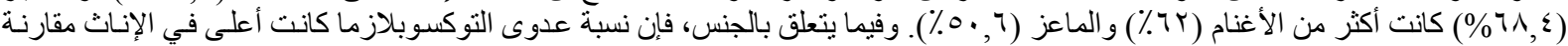

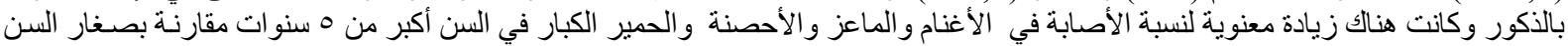

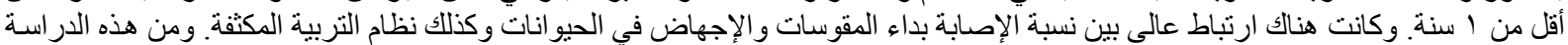

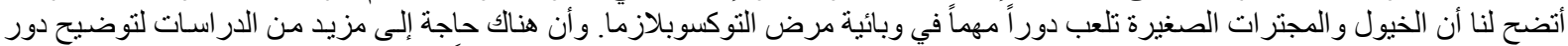

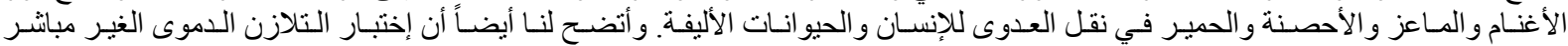

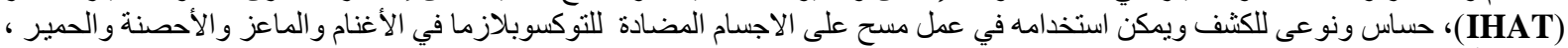

ويجب تأكيد نتائجه بإستخدام إختبار (ELISA). 